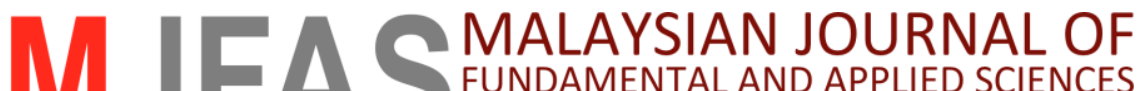

\section{Evaluation of environmental natural radioactivity levels in soil and ground water of Barkin Ladi, Plateau state, Nigeria.}

\author{
Habu Tela Abba a, ${ }^{*}$, Wan Muhamad Saridan Wan Hassan ${ }^{a}$, Muneer Aziz Saleh ${ }^{b}$ \\ a Department of Physics, Universiti Teknologi Malaysia, Skudai - 81310, Johor, Malaysia \\ b Nuclear Engineering Programme, Faculty of chemical and Energy Engineering, Universiti Teknologi Malaysia, Skudai - 81310, Johor, Malaysia \\ ${ }^{c}$ Department of Physics, Yobe State University Damaturu, Nigeria \\ * Corresponding author: htelaabba@gmail.com
}

Article history

Received 28 October 2017

Revised 23 May 2018

Accepted 4 July 2018

Published Online 3 September 2018

\section{Graphical abstract}

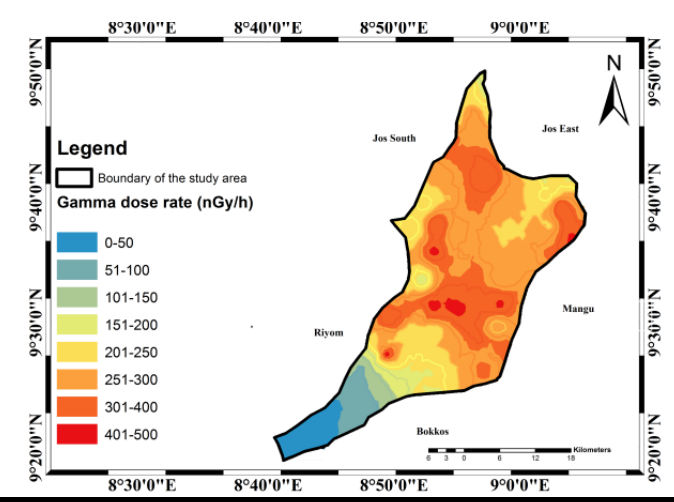

\begin{abstract}
Gamma spectrometry was used to measure gamma dose rate in air and to determine the activity concentration of naturally occurring radionuclides viz. ${ }^{226} \mathrm{Ra}{ }^{232} \mathrm{Th}$ and ${ }^{40} \mathrm{~K}$ in soil samples collected across the geological formations of Barkin Ladi. Dose rates measured in-situ ranged from 5 nGy $\mathrm{h}^{-1}$ to $1265 \mathrm{nGy} \mathrm{h}^{-1}$ with a mean value of $325 \mathrm{nGy} \mathrm{h} \mathrm{h}^{-1}$. The activity concentrations of ${ }^{226} \mathrm{Ra}$ ranged from 27 to $327 \mathrm{~Bq} \mathrm{~kg}^{-1}, 34$ to $457 \mathrm{~Bq} \mathrm{~kg}^{-1}$ for ${ }^{232} \mathrm{Th}$ and 43 to $1055 \mathrm{~Bq} \mathrm{~kg}^{-1}$ for ${ }^{40} \mathrm{~K}$. Their mean values are significantly higher than their corresponding global average values. Annual effective dose due to exposure to gamma dose is calculated at $0.34 \mathrm{mSv}^{-1}{ }^{-1}$. Mass concentrations of uranium ${ }^{238} \mathrm{U}$ ) and thorium $\left({ }^{232} \mathrm{Th}\right)$ determined in groundwater samples using Inductive Coupled Plasma Mass Spectrometry (ICP-MS) ranged from 2.5 to $35 \mu \mathrm{g} \mathrm{I}^{-1}$ for ${ }^{238} \mathrm{U}$ and 0.5 to $15 \mu \mathrm{g} \mathrm{I}^{-1}$ for ${ }^{232} \mathrm{Th}$. Ingestion effective dose varies between 10.5 and $142 \mathrm{mSv} \mathrm{y}^{-1}$ for ${ }^{238} \mathrm{U}$ and between 0.34 and $10.2 \mathrm{mSv}^{-1}$ for $^{232} \mathrm{Th}$. Mass concentration of three water samples exceed the toxicity limit of $U$ in groundwater provided by WHO. The result revealed that human risk due to ingestion of groundwater is from chemical toxicity rather than radiological effects. The results of this work will be useful for radio-geochemical investigation and groundwater
\end{abstract} resources management.

Keywords: Radioactivity, ${ }^{226} \mathrm{Ra},{ }^{232} \mathrm{Th}$ and ${ }^{40} \mathrm{~K}$, geological unit, ICP-MS, Barkin Ladi (c) 2018 Penerbit UTM Press. All rights reserved

\section{INTRODUCTION}

The occurrence of natural radioactivity in the environment depends on the types of rock formations, soils (Mangset et al., 2014) as well human activities in the area. Human activities include tin mining and use of fertilizers in agriculture. They are mainly release by primordial radionuclides such as the decay series of ${ }^{238} \mathrm{U}$ and ${ }^{232} \mathrm{Th}$; and non-decay series ${ }^{40} \mathrm{~K}$ contained in the earth crust most often referred to terrestrial radionuclides (Langmuir, 1978). Higher activity concentration of these radionuclides are associated with rocks that comprised of intrusive materials (UNSCEAR, 2000), such as granitic type of igneous rocks and pegmatites due the presence of uranium and thorium in considerable amount compared to low grade metamorphic and some sedimentary rocks (Aieta et al., 1987; Zapecza and Szabo, 1986).

Natural radionuclides exist in groundwater as a result of interaction between water and the rocks hosting the aquifer. Consumption of groundwater with elevated amounts of natural radionuclides may increase the radiotoxicity risk to human and internal exposure to radiation caused by the decay of the natural radionuclides taken into the body through ingestion as well as inhalation. The decay process leads to the release of several alpha and beta particles which are responsible for the total radiation dose received from natural radioactivity as well as artificial (Karahan G. et al., 2000). Relationship between radium in groundwater, local geology, and the total dissolved solids content (TDS) was investigated for North
Carolina (USA) by Michel (1991). In Nigeria, information on natural environmental radioactivity is sparse and limited; and no effort has been made to carry out an extensive field survey to cover its entire communities (Jibiri, 2001).

Barkin Ladi hosts a quite number of old tin mining locations which has drawn the attention of many researchers to investigate the levels of natural of radioactivity in the area as result of past tin mining activities for decades. Extraction and processing of tin minerals may cause the incorporation of radionuclides into the hydrosphere through surface or ground water (Pujol Li and Sanechez-Cebeza, 2000). Studies on natural radioactivity have been conducted previously in this area (Babalola, 1984; Oresegun and Babalola, 1990; Oresegun and Babalola, 1993; Sanni et al., 1985) but none them considered the incorporation geological settings of the area for this type of study. Mangset, et al. (2014) reported elevated level of gross alpha and beta activity concentration in groundwater for the same area. Recently, similar studies in the same region reported relatively higher dose rates (Abba et al., 2017a; Abba et al., 2017c) compared to other part of Nigeria (Jibiri and Farai, 1998).

Therefore, this study aims to determine the natural radioactivity levels in soil and groundwater based on geological formations in Barkin Ladi. This study will screen the radioactive background of the area which will enable the future estimate of radiological impact on the environment if any. 


\section{The study area}

Barkin Ladi local government area (LGA) is geographically located between the latitudes $9^{0} 25^{\prime} 08^{\prime}-9^{0} 42^{\prime} 48^{\prime \prime}$ north, and the longitudes $8^{0} 50^{\prime} 22^{\prime \prime}-8^{0} 58^{\prime} 22^{\prime \prime}$ east, in Plateau state of Nigeria. It has a total land area of $1,032 \mathrm{~km}^{2}$ and a population of 175,267 (NPC, 2006). It is bordered on the north by Jos South and Jos East LGAs, on the east by Mangu LGA, on the south by Bokkos LGA and to the west by Riyom LGA. The study area is characterised as tropical with temperature between $20^{\circ} \mathrm{C}$ to $22^{\circ} \mathrm{C}$ (Macleod et al., 1971).

Barkin Ladi is underlain by five bedrock formations broadly classified under three geological groups; namely basement complex of Precambrian age, Younger granites of Jos Plateau and Volcanic rocks of quaternary and tertiary ages as given in Table 1 and shown in Fig. 1. The basement complex is made-up of migmatite-gneiss-quartzite complexes which predominantly underlies the study area and in some places intruded by older granites, diorites, charnockite etc. The younger granites of Jos Plateau is of late Palaeozoic age (mostly Biotitegranites) are unconformably overlain by Cretaceous and younger sediments which are now partly exposed by erosion. The volcanic rocks is of tertiary origin which is associated with older basalts, quaternary newer basalts, pumice, lava flows and ash deposits. Minerals of economic important such as tin and columbite are also present in the area (Macleod, et al., 1971). Heavy radioactive minerals such as ilmenite, monazite and zircon are commonly found in reasonable quantities in tin mineral. These minerals contain radioactive elements, thorium and uranium (Hewson, 1996). Thus, appropriate radiation protection measures is timely required wherever these minerals are found, mined, processed and refined.In view of its geology and the decades of mining activities that took place in Barkin Ladi, measurement of natural radioactivity is timely required.

Table 1 Geological formations in Barkin Ladi.

\begin{tabular}{cll}
\hline Label & Geological unit & \multicolumn{1}{c}{ Composition } \\
\hline G1 & $\begin{array}{l}\text { Basalt, Trachyte } \\
\text { and Rhyolite }\end{array}$ & $\begin{array}{l}\text { Fine-grained, igneous rock } \\
\text { composed mainly of plagioclase } \\
\text { and pyroxene minerals overlaid by } \\
\text { a thick cap of lateritic ironstone. }\end{array}$ \\
G2 & Older Basalts & $\begin{array}{l}\text { Fine-grained, igneous rock mixed with } \\
\text { Posstasium Felspar. } \\
\text { Composed of felsic and felspatic } \\
\text { acidic intrusive } \\
\text { igneous rock. } \\
\text { Composed of grainy biotite } \\
\text { microgranites and some basic rocks. }\end{array}$ \\
G4 & Older Granites & Younger Granites
\end{tabular}

G5 Basement complex Sedimentary basins that are metamorphic or igneous in origin.

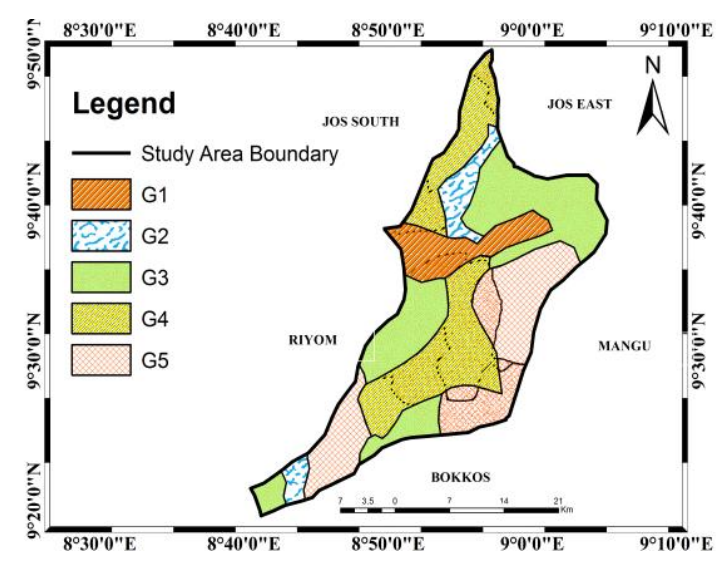

Fig. 1 Geological units of Barkin Ladi.

\section{Direct measurement of gamma dose rate}

Gamma dose rates measurement was conducted (in-situ) $1 \mathrm{~m}$ above ground surface using a portable $\mathrm{NaI}(\mathrm{Tl})$ survey meter manufactured by Ludlum measurement (Olise et al., 2014). Measurement were conducted at 192 different location across the five geological formation of the area. Coordinates of measurement locations were recorded with the aid of Global Positioning System (GPS), Garmin eTrex model 10. Gamma dose rate readings were recorded in in $\mu \mathrm{R} \mathrm{h}^{-1}$ which was later transformed to $\mathrm{nGy} \mathrm{h}^{-1}$ using a conversion factor 8.7 (Abba, et al., 2017c). The gamma dose rates obtained by the field survey is from both cosmic and terrestrial sources.

\section{Gamma ray spectrometry of soil samples}

A total of thirty seven top (at $0-30 \mathrm{~cm}$ depth) soils samples were collected across the geological units and far away from public structure. Coordinates of the sampling locations were also recorded as shown in Figure 2. At the laboratory, soil samples were cleared of stones, organic matters and other debris, dried to constant weight in an oven at $105^{\circ} \mathrm{C}$ and then homogenized. The prepared samples were filled in airtight $500 \mathrm{ml}$ standard Marinelli beakers to prevent escape of radon gas and kept for 30 days before radiometric analysis to achieve secular equilibrium between ${ }^{238} \mathrm{U}$ and ${ }^{232} \mathrm{Th}$ and their daughter products.

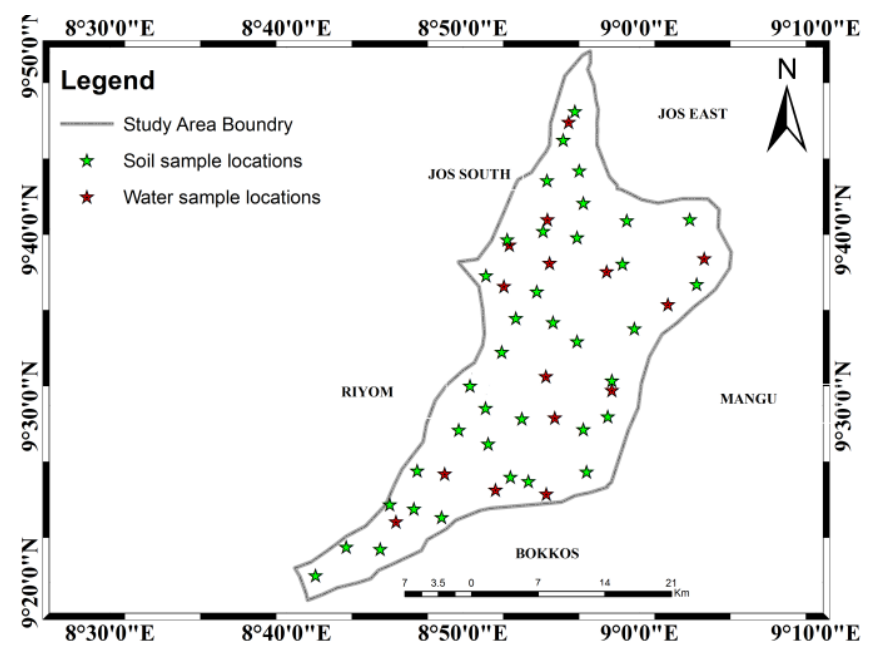

Fig. 2 Soil and groundwater samples locations.

Gamma emission from ${ }^{226} \mathrm{Ra},{ }^{232} \mathrm{Th}$ and ${ }^{40} \mathrm{~K}$ were measured using with a coaxial high purity germanium detector (GC2018-7500 SL) with a relative efficiency of $20 \%$, and resolution of $1.8 \mathrm{keV}$ at $1,332 \mathrm{keV}$ gamma ray emission of ${ }^{60} \mathrm{Co}$. The detector is coupled to 8192 multichannel analyzer (MCA) with a high voltage bias of 4,000 V (DC) through preamplifier. Genie 2000 (VI.3) software from Canberra was used to collect and analysed the spectra. Point sources were used for energy calibration whereas a mixed source was used for the efficiency calibration in the same geometry as the soil samples. IAEA reference materials (RG-U, RG-Th and RG-K) in the same size and volume as the soil samples were used as standards for comparison. To strip out emission from background radiation sources, an empty standard beaker was counted for the same length of time (six hours). The value of Minimum Detectable Activity (MDA) was computed to be $13 \mathrm{~Bq} \mathrm{~kg}^{-1}$ for ${ }^{40} \mathrm{~K}, 1 \mathrm{~Bq} \mathrm{~kg}^{-1}$ for ${ }^{226} \mathrm{Ra}$ and $2 \mathrm{~Bq} \mathrm{~kg}^{-1}$ for ${ }^{232} \mathrm{Th}$. The experiment was conducted at Nuclear Laboratory University Teknologi Malaysia.

At equilibrium, the energy peaks considered in the present analysis of the measured gamma-ray spectra are: ${ }^{214} \mathrm{~Pb}(352 \mathrm{keV})$ and ${ }^{214} \mathrm{Bi}$ $(609 \mathrm{keV})$, for ${ }^{226} \mathrm{Ra}$ and ${ }^{208} \mathrm{Tl}(583.1 \mathrm{keV})$ and ${ }^{228} \mathrm{Ac}(911.2 \mathrm{keV})$, for ${ }^{232} \mathrm{Th}$ and direct energy emission of $1461.8 \mathrm{keV}$ by ${ }^{40} \mathrm{~K}$ was used to determine its activity concentration. Total errors calculated due to activity measurement was typically in the range of 5-12\%, these include counting statistical errors and other systematic errors such as uncertainties in calibrations.

Following the spectrum analysis, specific activity of each radionuclide in the soil samples was computed using equation 1(Ademola and Farai, 2006; Isinkaye, 2013).

$$
C\left(B q k g^{-1}\right)=\frac{C_{n}}{\varepsilon p_{y} M_{s}}
$$

Since in-situ gamma dose rate measurement includes both cosmic and terrestrial gamma radiations, therefore, contribution of terrestrial 
radionuclides to the background gamma dose from activity concentrations of ${ }^{226} \mathrm{Ra},{ }^{232} \mathrm{Th}$ and ${ }^{40} \mathrm{~K}$ was obtained by equation 2 . The conversion factors used to estimate the absorbed dose rate is given by UNSCEAR (2000).

$$
D_{R}=\left(0.462 A_{R a}+0.604 A_{T h}+0.0417 A_{K}\right) n G y h^{-1}
$$

where, $0.462,0.604$ and 0.0417 are the activity concentration conversion factors of ${ }^{226} \mathrm{Ra},{ }^{232} \mathrm{Th}$ and ${ }^{40} \mathrm{~K}$, respectively to dose rate in air (UNSCEAR, 1998).

Annual effective dose (AED) outdoor due exposure to background gamma radiation dose for an individual in the area was calculated by the equation below:

$$
A E D\left(m S v y^{-1}\right)=D_{R} \times D_{E} \times F_{o c c} \times 24 \times 365 \times 10^{-6}
$$

where $D_{R}$ is the dose rate in $n G y h^{-1}, D_{E}$ is the is the conversion coefficient from absorbed dose in air to effective dose received by an adult given as $0.7\left(\mathrm{~Sv} \mathrm{~Gy}^{-1}\right)$ and $\mathrm{F}_{\text {occ }}$ is the the outdoor occupancy factor given by 0.2 (UNSCEAR, 2000).

\section{Measurement of uranium and thorium in groundwater}

A total of 15 groundwater samples from boreholes and hand dug wells were collected across the geological units for the analysis of uranium $\left({ }^{238} \mathrm{U}\right)$ and thorium $\left({ }^{232} \mathrm{Th}\right)$ mass concentrations. Samples were collected in clean plastic containers $(100 \mathrm{ml})$ at the sites and were stabilized with $5 \mathrm{ml}$ of nitric acid per litre and transported to laboratory for preparation and analysis. Locations of the sampling were recorded using GPS as shown in Fig. 2. Samples preparation and measurement were performed at Industrial Research Laboratory Universiti Teknologi Malaysia.

Inductive Coupled Plasma Mass spectrometry (ICP-MS) was used to determine the mass concentration of ${ }^{238} \mathrm{U}$ and ${ }^{232} \mathrm{Th}$. The instrument is manufactured by Perkin Elmer Corporation with model number NeXION 350 X. For reliability, each sample was measured in triplicate to check the reproducibility of the results. The samples and the calibration standards were measured for $55 \mathrm{~min}$. Syngistix software was used for data collection and intensity analysis. The lowest detection concentration of the instrument was $0.285 \mathrm{ng} \mathrm{l}^{-1}$ for ${ }^{232} \mathrm{Th}$ and $0.323 \mathrm{ng} \mathrm{l}^{-1}$ for ${ }^{238} \mathrm{U}$.

Annual ingestion effective dose equivalent due groundwater consumption is evaluated using conversion factors and annual water consumption rate of an adult proposed by US Environmental Protection Agency (US-EPA).The equation used is as follows:

$$
A D R_{w}=A_{R} \times I D F \times I_{w}
$$

where $\mathrm{ADR}_{\mathrm{w}}$ is the annual effective dose equivalent, $\mathrm{A}_{\mathrm{R}}$ is the activity concentration of ${ }^{238} \mathrm{U}$ or ${ }^{232} \mathrm{Th}, \mathrm{I}_{\mathrm{w}}$ annual water consumption rate (730 litres per annum) and IDF is the ingestion effective dose equivalent factor $\left(4.5 \times 10^{-1} \mathrm{mSv} \mathrm{Bq}^{-1}\right.$ and $2.3 \times 10^{-1} \mathrm{mSv} \mathrm{Bq}^{-1}$ for ${ }^{238} \mathrm{U}$ and $\left.{ }^{232} \mathrm{Th}\right)$.

\section{RESULTS AND DISCUSSION}

\section{Measurements of gamma dose rates}

The gamma dose rates varies between $55 \mathrm{nGy} \mathrm{h}^{-1}$ measured over geological unit basement complex (G5) and $1265 \mathrm{nGy} \mathrm{h}^{-1}$ noted on younger granites (G4) with a gross mean value of $325 \mathrm{nGy} \mathrm{h}^{-1}$, which is approximately six times the world average of $59 \mathrm{nGy} \mathrm{h}$ (UNSCEAR, 2000). The mean is also higher than the value reported by Abba, et al. (2017c) for the same region. Dose rates distribution for this study is presented as frequency distribution curve in Fig. 3.

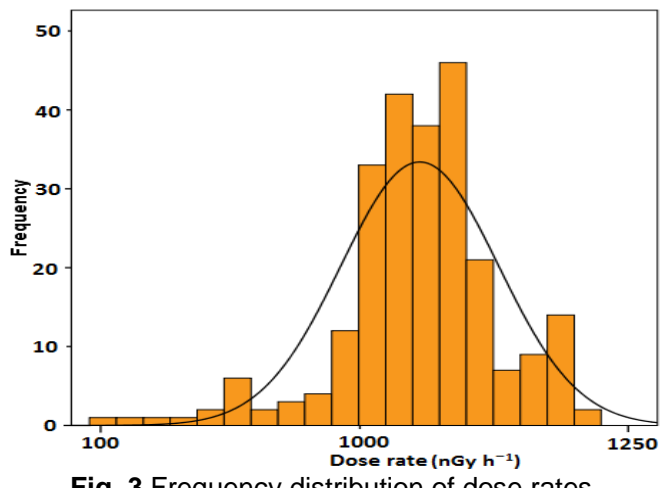

Fig. 3 Frequency distribution of dose rates.

The activity concentration of the radionuclides were determined to be in the range of 27 to $327 \mathrm{~Bq} \mathrm{~kg}^{-1}$ for ${ }^{226} \mathrm{Ra}, 34$ to $457 \mathrm{~Bq} \mathrm{~kg}^{-1}$ for ${ }^{232} \mathrm{Th}$ and from 43 to $1055 \mathrm{~Bq} \mathrm{~kg}^{-1}$ for ${ }^{40} \mathrm{~K}$. Descriptive statistics of the activity concentration and the calculated dose rate is presented in Table 2. The mean values were found to be significantly higher than their corresponding world average values of $35 \mathrm{~Bq} \mathrm{~kg}^{-1}, 45 \mathrm{~Bq} \mathrm{~kg}^{-1}$ and 420 $\mathrm{Bq} \mathrm{kg}^{-1}$ for ${ }^{226} \mathrm{Ra},{ }^{232} \mathrm{Th}$ and ${ }^{40} \mathrm{~K}$, respectively (UNSCEAR, 2000) and distinctly lower than values of $4200 \mathrm{~Bq} \mathrm{~kg}^{-1}$ for ${ }^{226} \mathrm{Ra}$ and $18000 \mathrm{~Bq}$ $\mathrm{kg}^{-1}$ for ${ }^{232} \mathrm{Th}$ reported by Arogunjo et al. (2009) for the same region. The variation could be due to the fact that samples were directly collected from tin mining locations for analysis in the earlier study.

Table 2 Descriptive statistics for the activity concentration of ${ }^{226} \mathrm{Ra}$,

${ }^{232} \mathrm{Th}$ and ${ }^{40} \mathrm{~K}$ and the calculated dose rate.

\begin{tabular}{lllll}
\hline Statistic & $\begin{array}{c}{ }^{226} \mathbf{R a} \\
\left(\mathrm{Bq} \mathrm{kg}^{-1}\right)\end{array}$ & $\begin{array}{c}{ }^{232} \mathbf{T h} \\
\left(\mathrm{Bq} \mathrm{kg}^{-1}\right)\end{array}$ & $\begin{array}{c}{ }^{40} \mathbf{K} \\
\left(\mathrm{Bq} \mathrm{kg}^{-1}\right)\end{array}$ & $\begin{array}{l}\text { Dose rate } \\
(\mathbf{n G y ~ h - 1})\end{array}$ \\
\hline Mean & 153 & 345 & 453 & 298 \\
Range & $27-327$ & $34-457$ & $43-1055$ & $35-471$ \\
Std. Error & 6 & 13 & 33 & 11 \\
Std. Dev. & 46 & 90 & 234 & 76 \\
95\% conf. & $131-173$ & $318-374$ & $385-523$ & $281-328$ \\
interval for & & & & \\
mean & & & & \\
\hline
\end{tabular}

The mean activity concentration of ${ }^{226} \mathrm{Ra},{ }^{232} \mathrm{Th}$ and ${ }^{40} \mathrm{~K}$ for each geological unit is given in Fig. 6(a) and the calculated absorbed dose rate in Fig. 6(b). The highets activity concentration of ${ }^{226} \mathrm{Ra}$ was measured in soil sample collected from areas of geological unit basement complex (G5) and lowest in soil sample from areas of older granites (G3). The higher concentration of ${ }^{226} \mathrm{Ra}$ in basement complex could be linked to the substantial amount of $U$ and $T h$ contained in igneous rocks (UNSCEAR, 2000), while its lower concentration may be linked to the little layer of basaltic formation associated with the older granites in the region (Abba et al., 2017b). This results is in consistent with similar studies (Ramli et al., 2001; Saleh et al., 2013a). Highest mean activity concentration of ${ }^{232} \mathrm{Th}$ was oberved in soil sample from areas of older granites and the lowest was in areas of younger granites (G4). The basic rocks mixed with the younger granites could be the reason for lower activity concentration of ${ }^{232} \mathrm{Th}$. For ${ }^{40} \mathrm{~K}$, the highest activity concentration was measured in soil sample from areas of older basalt (G2) which could be attributed to the mineral potassium felspar that is mixed with this formation. The lowest mean of ${ }^{40} \mathrm{~K}$ is measured in soil sample from areas of younger granites.
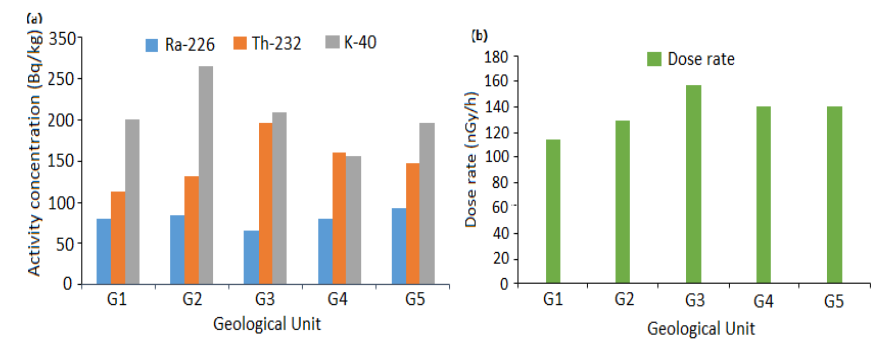

Fig. 6. Activity concentrations of ${ }^{226} \mathrm{Ra},{ }^{232} \mathrm{Th}$ and ${ }^{40} \mathrm{~K}$ and dose rate for each geological unit presented in left and right places, respectively. 
The activity concentration was used to calculate the terrestrial gamma radiation absorbed dose rate in air for the area and was found to ranged between 35 and $471 \mathrm{nGy} \mathrm{h}^{-1}$ with a mean value of $298 \mathrm{nGy} \mathrm{h}^{-1}$. The dose rate in Barkin Ladi was found to be largely contributed by ${ }^{232} \mathrm{Th}(69 \%)$ followed by ${ }^{226} \mathrm{Ra}$ and ${ }^{40} \mathrm{~K}$ contributing $25 \%$ and $6 \%$, respectively. Figue 4 presents dose rate distribution map for the area. This estimates is comparatively higher than that reported by Obed et al. (2005) for eighteen majors cities in Nigeria. Their results of gamma dose rate ranged from 19 to $88 \mathrm{nGy} \mathrm{h}^{-1}$ with a gross mean of $42 \mathrm{nGy} \mathrm{h}^{-1}$. The calculated mean dose rate of the current work is found to be $7 \%$ lower than that of the measured dose rate which represent the contributions from the cosmic and other sources.

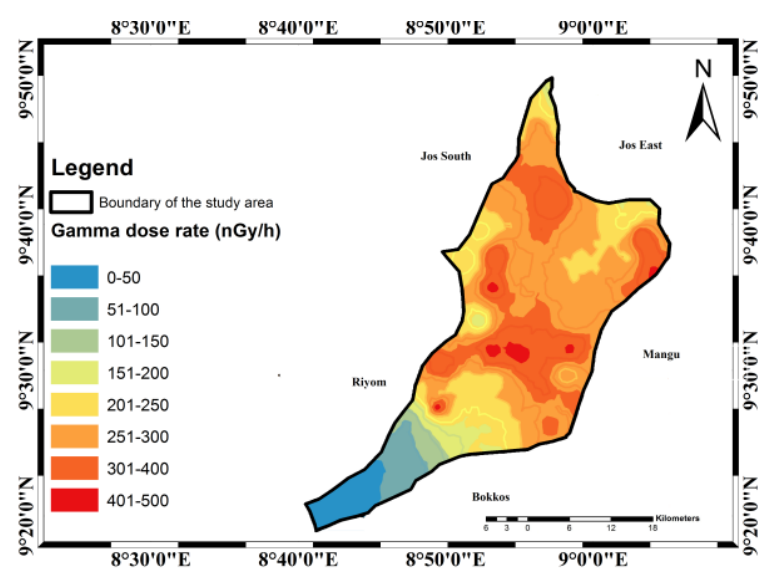

Fig. 4 Isodose of gamma dose rate for the area.

A positive correlation $(\mathrm{R}=0.923)$ was observed between the measured and the calculated dose rates as shown in Fig. 5. The nonzero intercept is assumed to a contribution from cosmic and other terrestrial radionuclides (Saleh, et al., 2013a). The measured dose rates were corrected by multiplying with a factor of $1 / 0.851$.

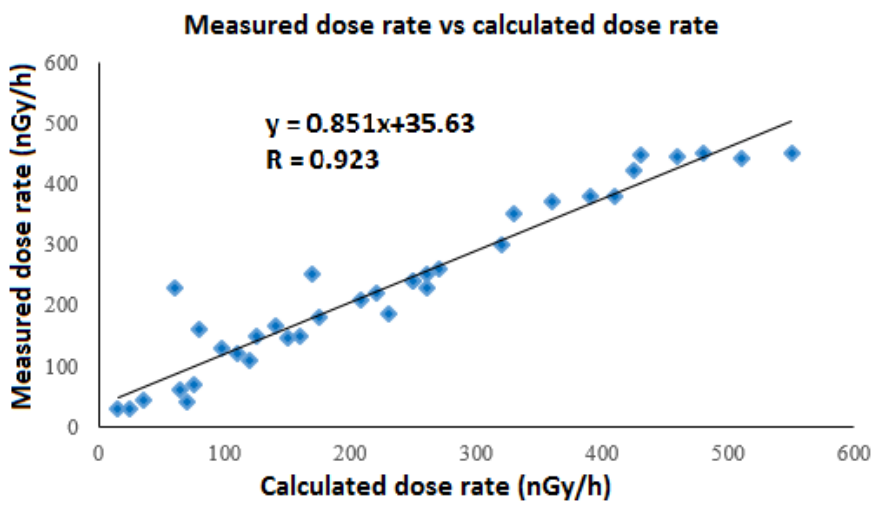

Fig. 5 Correlation between measured and calculated dose rates.

\section{Mass concentration of ${ }^{228} \mathrm{U}$ and ${ }^{232} \mathrm{Th}$ in groundwater}

Fig. 7 presents the mass concentration for the 15 water samples collected from various sources across the geological formations in Barkin Ladi. The mass concentration of ${ }^{238} \mathrm{U}$ and ${ }^{232} \mathrm{Th}$ in the groundwater samples ranged from $2.5 \mu \mathrm{g} \mathrm{l}^{-1}$ (W1) measured in a water sample from areas of geological formation basalts, trachyte and rhyolite (G1) which consist of lateritic ironstone to $35 \mu \mathrm{g} \mathrm{l}^{-1}$ (W11) noted in an aquifer confined by older granites (G3), this rock composed of acidic intrusive materials which contained minerals hosting $U$ and $T h$ in reasonable quantity. Three water samples were found to exceed reference level of $30 \mu \mathrm{g} \mathrm{l}^{-1}$ set by World health organisation (WHO, 2011) and US Environmental Protection Agency (USEPA, 2008).

Mass concentration of ${ }^{232} \mathrm{Th}$ was found to ranged between $0.5 \mu \mathrm{g}$ $\mathrm{l}^{-1}$ and $15 \mu \mathrm{g} \mathrm{l}^{-1}$ with highest measured in areas of younger granites (G4) and lowest in an aquifer hosted by basement complex (G5). Mass concentration of ${ }^{238} \mathrm{U}$ was observed to be higher than ${ }^{232} \mathrm{Th}$ in all the samples except W4 and W5, this could be linked to its high mobility in all environmental conditions while stable nature of ${ }^{232} \mathrm{Th}$ making it insoluble in aqueous solution (Saleh et al., 2015).

The elemental concentrations of ${ }^{238} \mathrm{U}$ and ${ }^{232} \mathrm{Th}$ were converted to activity concentrations using conversion factors $\left(1 \mu \mathrm{g} \mathrm{l}^{-1}\right.$ $\left.=12.35 \mathrm{mBq} \mathrm{l}^{-1}\right)$ for ${ }^{238} \mathrm{U}$ and $\left(1 \mu \mathrm{g}^{-1}=4.06 \mathrm{mBq}^{-1}\right)$ for ${ }^{232} \mathrm{Th}$ (IAEA, 1989). The activity concentrations ranged from $31 \mathrm{mBq}^{-1}$ to $432 \mathrm{mBq}$ $\mathrm{l}^{-1}$ for ${ }^{238} \mathrm{U}$ and ranged between $2 \mathrm{mBq} \mathrm{l}^{-1}$ and $61 \mathrm{mBq} \mathrm{l}^{-1}$ for ${ }^{232} \mathrm{Th}$. Activity concentration levels in all the groundwater samples are generally lower than the refence value of $1 \mathrm{~Bq}^{-1}$ and $0.5 \mathrm{~Bq} \mathrm{l}^{-1}$ for ${ }^{238} \mathrm{U}$ and ${ }^{232} \mathrm{Th}$, respectively.

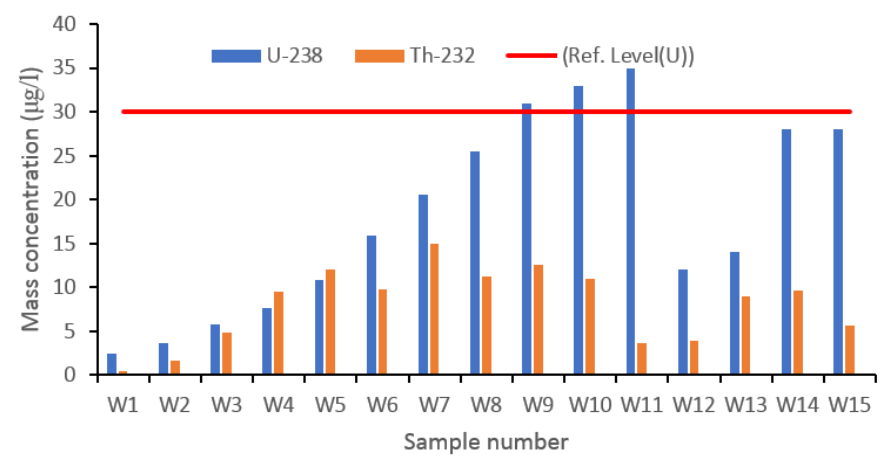

Fig. 7 Mass concentrations of ${ }^{238} \mathrm{U}$ and ${ }^{2322} \mathrm{Th}$ in groundwater samples.

Annual mean effective doses due to exposure to gamma radiation dose was calculated at $0.34 \mathrm{mSv} \mathrm{y}^{-1}$ (equation 3 ). The annual effective dose due ingestion of groundwater in Barkin Ladi ranged between 10.5 - $142 \mathrm{mSv} \mathrm{y}^{-1}$ for ${ }^{238} \mathrm{U}$ and between $0.34-10.2 \mathrm{mSv} \mathrm{y}^{-1}$ for ${ }^{232} \mathrm{Th}$ (equation 4). Water samples from three sources have annual effective dose exceeding the refence limit of $0.1 \mathrm{mSv} \mathrm{y}^{-1}$ provided by WHO (2011).

\section{CONCLUSION}

Gamma spectrometry was used to measured the external gamma dose rates and to determined the activity concentration ${ }^{226} \mathrm{Ra},{ }^{232} \mathrm{Th}$ and ${ }^{40} \mathrm{~K}$ is soil across the geological formations of Barkin Ladi. Dose rates measured in-situ was found to ranged from $5 \mathrm{nGy} \mathrm{h}^{-1}$ to $1265 \mathrm{nGy} \mathrm{h}^{-1}$ with a mean value of $325 \mathrm{nGy} \mathrm{h}^{-1}$. Activity concentration of ${ }^{226} \mathrm{Ra}$, ${ }^{232} \mathrm{Th}$ and ${ }^{40} \mathrm{~K}$ ranged from 27 to $327 \mathrm{~Bq} \mathrm{~kg}^{-1}$, from 34 to $457 \mathrm{~Bq} \mathrm{~kg}^{-1}$ and from 43 to $1055 \mathrm{~Bq} \mathrm{~kg}^{-1}$, for ${ }^{226} \mathrm{Ra},{ }^{232} \mathrm{Th}$ and ${ }^{40} \mathrm{~K}$, respectively, while the calculated dose rates was found to ranged between 35 to $471 \mathrm{nGy} \mathrm{h}^{-1}$ with a mean value of $298 \mathrm{nGy} \mathrm{h}^{-1}$. Gamma dose rates was found to be largely $(69 \%)$ contributed by ${ }^{232} \mathrm{Th}$. Higher concentration of ${ }^{226} \mathrm{Ra}$ was meassured in areas of basement complex (G5), whereas that of ${ }^{232} \mathrm{Th}$ and ${ }^{40} \mathrm{~K}$ were recorded in soil samples from areas of older granites (G3) and older basalt (G2), respectively.

Mass concentrations of ${ }^{38} \mathrm{U}$ and ${ }^{232} \mathrm{Th}$ in groundwater samples were determined using Inductive Coupled Plasma Mass Spectrometry and the concentration ranged betwenn 2.5 and $35 \mu \mathrm{g}^{-1}$ for ${ }^{238} \mathrm{U}$ and $0.5 \mu \mathrm{g}$ $\mathrm{l}^{-1}$ and $15 \mu \mathrm{g} \mathrm{l}^{-1}$ for ${ }^{232} \mathrm{Th}$. Their corresponding activity concentration in the water samples ranged from $31-432 \mathrm{mBq} \mathrm{l}^{-1}$ for ${ }^{238} \mathrm{U}$ and $2 \mathrm{mBq}^{-1}$ to $61 \mathrm{mBq} \mathrm{l}^{-1}$ for ${ }^{232} \mathrm{Th}$. Mass concentration of three water samples were found to exceed the reference limit of of $30 \mu \mathrm{g} 1^{-1}$ in drinking water recommended by WHO, but radiologically safe. Annual effective dose due to exposure to gamma dose was calculated at 0.34 $\mathrm{mSv} \mathrm{y}^{-1}$ and annual ingestion effective dose equivalent due to consumption of groundwater ranged between 10.5 and $142 \mathrm{mSv} \mathrm{y}^{-1}$ for ${ }^{238} \mathrm{U}$ and between 0.34 and $10.2 \mathrm{mSv} \mathrm{y}^{-1}$ for ${ }^{232} \mathrm{Th}$.

The results presented, will be useful for future radio-geochemical investigations in the area and also useful for water resources management and protection of groundwater resources.

\section{ACKNOWLEDGEMENT}

This work is conducted with some financial support from the Ministry of Science, Technology and Innovation (MOSTI), Malaysia (Grant No. R.J130000.7926.4S109). Our gratitude goes to the staff members of Nuclear Laboratory Universiti Teknologi Malaysia for their technical support. 


\section{REFERENCES}

Abba, H., Saleh, M., Hassan, W., Aliyu, A. and Ramli, A. (2017). Mapping of natural gamma radiation (NGR) dose rate distribution in tin mining areas of Jos Plateau, Nigeria. Environmental Earth Sciences, 76(5), 208.

Abba, H. T., Hassan, W. M. S. W., Saleh, M. A., Aliyu, A. S. and Ramli, A. T. (2017). Estimation of Terrestrial gamma radiation (TGR) dose rate in characteristic geological formations of Jos Plateau, Nigeria. Malaysian Journal of Fundamental and Applied Sciences, 13(4), 593-597.

Abba, H. T., Hassan, W. M. S. W., Saleh, M. A., Aliyu, A. S. and Ramli, A. T. (2017c). Terrestrial gamma radiation dose (TGRD) levels in northern zone of Jos Plateau, Nigeria: Statistical relationship between dose rates and geological formations. Radiation Physics and Chemistry, 140, 167-172

Ademola, J. and Farai, I. (2006). Gamma activity and radiation dose in concrete building blocks used for construction of dwellings in Jos, Nigeria. Radiation protection dosimetry, 121(4), 395-398.

Aieta, E. M., Singley, J. E., Trussell, A. R., Thorbjarnarson, K. W. and McGuire, M. J. (1987). Radionuclides in drinking water: An overview. American Water Works Association Journal, 79, 144-152.

Arogunjo, A. M., llriegl, V. H., Giussani, A., Leopold, K., Gerstmann, U., Veronese, I. and Oehb, U. (2009). Uranium and thorium in soils mineral sands water and food samples in a tin mining area in Nigeria with elevated activity. Journal of Environmental Radioactivity, 100(3), 232-240.

Babalola, I. (1984). Radiation measurement and assay of tailing from high natural radioactivity in Plateau State. Nigerian Journal of Science. 18, 98 101.

Hewson, G. (1996). Overview of radiation safety in the tin by-product (amang) industry of South East Asia. Health physics. 71(2), 225-234.

International Atomic Energy Agency (1989). Construction and use of calibration Facilities for radiometric field equipment. Technical Reports Series no.309, Vienna: IAEA.

Isinkaye, M. (2013). Natural radioactivity levels and the radiological health implications of tailing enriched soil and sediment samples around two mining sites in Southwest Nigeria. Radiation Protection and Environment $36(3), 122-127$

Jibiri, N. (2001). Assessment of health risk levels associated with terrestrial gamma radiation dose rates in Nigeria. Environment International. 27(1), 21-26.

Jibiri, N. and Farai, I. (1998). Assessment of dose rate and collective effective dose equivalent due to terrestrial gamma radiation in the city of Lagos, Nigeria. Radiation Protection Dosimetry. 76(3), 191-194.

Karahan G., Ozturk N. and Ahmet B. (2000). Natural Radioactivity in various surface waters in Istanbul, Turkey. Water Resources, 24, 4367 - 4370.

Langmuir, D. (1978). Uranium solution-mineral equilibria at low temperatures with applications to sedimentary ore deposits. Geochimica et Cosmochimica Acta, 42(6), 547-569.

Macleod, W. N., Turner, D. C. and Wright, E. P. (1971). The Geology of Jos Plateau. Bulletin Geological Survey of Nigeria, 32(1), 12-47.
Mangset, W., Ike, E., Christopher, L., Solomon, A. and Mallam, S. (2014). Evaluation of the radiation hazard indices and excess life time cancer risk due to natural radioactivity in ground water in mining areas of plateau state. International Journal of Engineering, 5(05), 9-23.

Michel, J. (1991). Relationship of radium and radon with geological formations. In: Richard Cothern, C., Rebers, P.A. (Eds.). Radon, Radium and Uranium in Drinking Water, Second Ed. USA: Lewis Publishers, 83 e96.

NPC (2006). National population Commission (NPC): Provisional of 2006 CensusResults.Retrieved From

https://www.jstor.org/stable/25434601?seq=1\#page_scan_tab_contents.

Obed, R., Farai, I. and Jibiri, N. (2005). Population dose distribution due to soil radioactivity concentration levels in 18 cities across Nigeria. Journal of Radiological Protection, 25(3), 305-312.

Olise, F. S., Oladejo, O. F., Almeida, S. M., Owoade, O. K., Olaniyi, H. B. and Freitas, M. C. (2014). Instrumental neutron activation analyses of uranium and thorium in samples from tin mining and processing sites. Journal of Geochemical Exploration, 142, 36-42.

Oresegun, M. and Babalola, A. (1990). Occupational radiation exposure associated with milling of Th-U-rich Sn ore in Nigeria. Health Physics. 58(2), 213-215.

Oresegun, M. and Babalola, I. (1993). The environmental gamma radiation level of Jos, Nigeria. Nigerian Journal of Science, 27, 263-268.

Pujol Li. and Sanechez-Cebeza, J. A. (2000). Natural and and artificial radioactivity in surface waters of the Ebro River Basin (Northeast Spain). Journal of Environment Radioactivity, 51,181-210.

Ramli, A. T., Hussein, A. W. M. and Lee, M. (2001). Geological influence on terrestrial gamma radiation dose rate in the Malaysian State of Johore. Applied Radiation and Isotopes, 54(2), 327-333.

Saleh, M. A., Ramli, A. T., Alajerami, Y., Aliyu, A. S. and Basri, N. A. B. (2013a). Radiological study of Mersing District, Johor, Malaysia. Radiation Physics and Chemistry, 85, 107-117.

Saleh, M. A., Ramli, A. T., Bin Hamzah, K., Alajerami, Y., Mhareb, M. H. A., Aliyu, A. S. and Hanifah, N. Z. H. B. A. (2015). Natural environmental radioactivity and the corresponding health risk in Johor Bahru District, Johor, Malaysia. Journal of Radioanalytical and Nuclear Chemistry, 303(3), 1753-1761.

Sanni, A., James, D. and Schweikert, E. (1985). Radioactivity of the by-products of tin mining in Nigeria. Nigerian Journal of Science. 20, 115-120

UNSCEAR (2000). Sources, Effects and Rsik of Ionizing Radiation. United Nation Scientific Commitee on the Effect of Atomic RadiationNew York; United Nations.

United Nations Scientific Committee on the Effects Atomic Radiation (2000). Sources and effects of ionizing radiation. Report to the General Assembly with Scientific Annexes. New York: United Nations.

US Environmental Protection Agency (2008). Groundwater and Drinking water. US Drinking water Division Retrieved from. (http://water.epa.gov/drink/).

World. Health Organization (2003). Guidelines for Drinking-Water Quality Health Cretirea and other supporting information. 2nd edition, vol. 2; pp. 367-370.

Zapecza, O. S. and Szabo, Z. (1986). Natural radioactivity in ground water - A review. US Geological Survey National Water Summary, 50-57. 